MARTINS, C.C.; BOVI, M.L.A.; NAKAGAWA, J.; GODOY JÚNIOR. G. Temporary storage of jussara palm seeds: effects of time, temperature and pulp on germination and vigor. Horticultura Brasileira, Brasília, v.22, n.2, p.271-276, abril-junho 2004.

\title{
Temporary storage of jussara palm seeds: effects of time, temperature and pulp on germination and vigor
}

\author{
Cibele C. Martins' ${ }^{1}$; Marilene L. A. Bovi ${ }^{3}$; João Nakagawa² ${ }^{2}$ Gentil Godoy Júnior ${ }^{4}$ \\ ${ }^{1}$ FAPESP scholarship; ${ }^{2} \mathrm{CNPq}$ scholarship; ${ }^{12} \mathrm{FCA} / \mathrm{UNESP}, \mathrm{C}$. Postal 237, 18603-970 Botucatu-SP, E-mail: secdamv@fca.unesp.br; \\ ${ }^{3}$ Centro de Horticultura IAC/SAA, C. Postal 28, 13001-970 Campinas-SP, E-mail: mlabovi@iac.sp.gov.br; ${ }^{4}$ IAC/SAA, Rod. Oswaldo \\ Cruz, 5061, 11680-000 Ubatuba-SP
}

\begin{abstract}
Seeds of jussara palm (Euterpe edulis Mart.) are recalcitrant, presenting low longevity, high sensitivity to dehydration and to low temperatures of storage. Temperature conditions for temporary preservation of those seeds, with and without pulp, were studied. Mature fruits were harvested from 24 plants belonging to the palm collection of the Instituto Agronômico (IAC) located at Ubatuba, São Paulo State, Brazil, and taken in moisture-proof containers to the Universidade Estadual de São Paulo, in Botucatu, São Paulo State. Half of the fruits were shelled and the seeds stored, with and without pulp, in sealed plastic bags $(20 \mu \mathrm{m}$ thick) maintained in chambers with temperatures of $5 ; 10 ; 15$ and $20-30^{\circ} \mathrm{C}$. Samples for the quality tests were taken at $0 ; 3 ; 6 ; 9$ and 12 days after fruit harvest. Seeds stored with pulp were immediately shelled before test installation. Several characteristics were evaluated, especially seed water content, germination rate, seedling length and dry matter. There is a positive after-ripening effect on Euterpe edulis seeds. A period of storage of 9 to 12 days, after fruit harvest and before sowing, favored germination and vigor of jussara seeds. These effects were higher in shelled seeds when compared to unshelled ones. Shortterm storage temperatures ranging from 5 to $20-30^{\circ} \mathrm{C}$ are equally adequate for the preservation of seeds without pulp, but should not exceed $20^{\circ} \mathrm{C}$ for those with pulp, since a decrease in germination and vigor, and an increase in rotted germinative button and dead seeds were observed at $20-30^{\circ} \mathrm{C}$ temperature.
\end{abstract}

Keywords: Euterpe edulis, conservation, heart of palm, propagation, recalcitrant.

\begin{abstract}
RESUMO
Armazenamento temporário de sementes da palmeira juçara: efeitos do tempo, temperatura e polpa na germinação $e$ vigor
\end{abstract}

As sementes da palmeira juçara (Euterpe edulis Mart.) são recalcitrantes, apresentando baixa longevidade e sensibilidade à desidratação e ao armazenamento em temperaturas baixas. Neste trabalho foram estudadas condições de temperatura mais adequadas ao armazenamento temporário destas sementes com e sem a polpa. Frutos maduros foram colhidos em 24 plantas provenientes da coleção de palmeiras do Instituto Agronômico (IAC) localizada em Ubatuba, estado de São Paulo, e encaminhadas, em embalagem impermeável, à Faculdade de Ciências Agronômicas da UNESP, Campus de Botucatu (SP). Metade dos frutos foi despolpada e outra metade foi mantida com polpa, sendo ambas armazenadas em sacos fechados de polietileno ( $20 \mu \mathrm{m}$ de espessura) mantidos em temperaturas de 5; $10 ; 15$ e $20-30^{\circ} \mathrm{C}$. Amostras para os testes de qualidade foram retiradas aos $0 ; 3 ; 6 ; 9$ e 12 dias após a colheita dos frutos. As sementes armazenadas com polpa foram despolpadas imediatamente antes da instalação dos testes. Foram avaliados o grau de umidade das sementes, porcentagem de germinação, comprimento e matéria seca das plântulas. Os resultados mostraram que há efeito positivo de pós-amadurecimento em sementes de Euterpe edulis. Um período de armazenamento de 9 a 12 dias, após a colheita e antes da semeadura, favoreceu a germinação e o vigor das sementes de juçara. Os efeitos foram maiores para sementes armazenadas sem polpa do que com polpa. Temperaturas na faixa de 5 a $20-30^{\circ} \mathrm{C}$ são igualmente adequadas para o armazenamento temporário de sementes sem polpa. No entanto, para sementes com polpa, a temperatura de armazenamento não deve exceder a $20^{\circ} \mathrm{C}$, visto que um decréscimo na germinação e no vigor e um acréscimo no número de botões germinativos apodrecidos e sementes mortas foram observados na temperatura de $20-30^{\circ} \mathrm{C}$.

Palavras-chave: Euterpe edulis, conservação, palmito, propagação, recalcitrante.

(Recebido para publicação em 13 de fevereiro de 2003 e aceito em 20 de março de 2004)

$\mathrm{T}$ he species Euterpe edulis Mart., a single stemmed palm from Brazilian Atlantic Forest, known as jussara palm, has being exploited in a predatory pattern over several decades for heart-of-palm or palmito production, a product valued in the internal and external market (Orlande et al., 1996; Galetti \& Fernandez, 1998; Matos \& Bovi, 2002). In order to fulfill the demand, millions of palms are cut, every year, before they reach maturity and produce seeds, the only propagation method of this species. The presence of urban centers bordering forestal areas has resulted in deforestation and illegal occupation for urban construction, cultivation and/or mining. Due to indiscriminate exploration and natural habitat destruction, most of the jussara populations have been drastically reduced. Nowadays, the search for seeds for commercial cultivation and for establishment of programs of native forests recomposition have been increasing, making necessary the development of favorable technologies aiming the production and preservation of high quality E. edulis seeds.

Jussara seeds are recalcitrant, presenting low longevity and sensitivity 
Table 1. Means of different traits utilized for Euterpe edulis germination and vigor evaluations, considering simple and interaction effects of storage time, temperature and pulp (presence or absence). Botucatu, UNESP, 1998.

\begin{tabular}{|c|c|c|c|c|c|c|c|c|c|}
\hline \multirow{2}{*}{ Storage } & \multirow{2}{*}{$\begin{array}{l}\text { Seed } \\
\text { water } \\
\text { conte- } \\
\text { nt (\%) }\end{array}$} & \multirow{2}{*}{$\begin{array}{l}\text { Seedling dry } \\
\text { weight (mg/ } \\
\text { seedling) }\end{array}$} & \multicolumn{3}{|c|}{ Seedling length $(\mathrm{mm})$} & \multirow{2}{*}{$\begin{array}{c}\text { Rotted } \\
\text { germinative } \\
\text { button }\end{array}$} & \multirow{2}{*}{$\begin{array}{c}\text { Abnormal } \\
\text { seedling }\end{array}$} & \multirow{2}{*}{$\begin{array}{l}\text { Dead seed } \\
\%)\end{array}$} & \multirow{2}{*}{$\begin{array}{c}\text { Final } \\
\text { germination }\end{array}$} \\
\hline & & & Plumule & Radicle & Total & & & & \\
\hline \multicolumn{10}{|l|}{ Time (days) } \\
\hline 0 & 49.4 & $9.67 \mathrm{c}$ & $9.33 \mathrm{~b}$ & $29.35 d$ & $38.67 \mathrm{~d}$ & $2.00 \mathrm{a}$ & $1.00 \mathrm{a}$ & $9.00 \mathrm{a}$ & $88.00 \mathrm{~b}$ \\
\hline 3 & 49.8 & $11.79 \mathrm{~b}$ & $9.54 \mathrm{~b}$ & $33.45 \mathrm{bc}$ & $42.99 \mathrm{bc}$ & $1.87 \mathrm{a}$ & $1.87 \mathrm{a}$ & $6.50 a b$ & $89.75 \mathrm{~b}$ \\
\hline 6 & 49.4 & $11.87 \mathrm{~b}$ & $9.48 \mathrm{~b}$ & $32.40 \mathrm{c}$ & $41.55 \mathrm{c}$ & $1.50 \mathrm{ab}$ & $1.37 \mathrm{a}$ & $6.62 a b$ & $90.50 \mathrm{~b}$ \\
\hline 9 & 50.0 & $14.12 \mathrm{a}$ & $10.49 \mathrm{a}$ & $36.04 \mathrm{a}$ & $46.40 \mathrm{a}$ & $2.25 \mathrm{a}$ & $1.00 \mathrm{a}$ & $6.50 \mathrm{ab}$ & $90.25 b$ \\
\hline 12 & 50.1 & $14.07 \mathrm{a}$ & $10.57 \mathrm{a}$ & $34.52 \mathrm{ab}$ & $44.59 \mathrm{ab}$ & $0.12 b$ & $0.62 \mathrm{a}$ & $4.87 \mathrm{~b}$ & 94.37 a \\
\hline \multicolumn{10}{|c|}{ Temperature $\left({ }^{\circ} \mathrm{C}\right)$} \\
\hline 5 & 49.8 & $12.14 \mathrm{bc}$ & $9.90 \mathrm{ab}$ & $32.66 \mathrm{ab}$ & $42.44 a b$ & $1.80 \mathrm{a}$ & $1.40 \mathrm{a}$ & $7.10 \mathrm{a}$ & $89.70 a b$ \\
\hline 10 & 49.8 & $12.65 a b$ & $9.92 a b$ & $34.21 \mathrm{a}$ & $43.78 \mathrm{a}$ & $1.20 \mathrm{a}$ & $0.90 \mathrm{a}$ & $5.80 \mathrm{a}$ & $92.10 \mathrm{a}$ \\
\hline 15 & 49.8 & $12.79 \mathrm{a}$ & $10.11 a$ & $33.86 \mathrm{ab}$ & $43.66 \mathrm{a}$ & $1.00 \mathrm{a}$ & $1.50 \mathrm{a}$ & $6.10 a$ & $91.40 a b$ \\
\hline $20-30$ & 49.7 & $11.64 \mathrm{c}$ & $9.60 \mathrm{~b}$ & $31.88 \mathrm{~b}$ & $41.48 \mathrm{~b}$ & $2.20 \mathrm{a}$ & $0.90 \mathrm{a}$ & $7.80 \mathrm{a}$ & $89.10 \mathrm{~b}$ \\
\hline \multicolumn{10}{|l|}{ Pulp } \\
\hline With & 49.8 & $11.63 \mathrm{~b}$ & $9.62 \mathrm{~b}$ & $31.62 \mathrm{~b}$ & $41.04 \mathrm{~b}$ & $1.75 \mathrm{a}$ & $1.30 \mathrm{a}$ & $7.90 \mathrm{a}$ & 89.05 b \\
\hline Without & 49.7 & $12.97 \mathrm{a}$ & $10.14 a$ & $34.68 a$ & $44.64 \mathrm{a}$ & $1.35 a$ & $1.05 \mathrm{a}$ & $5.50 \mathrm{~b}$ & $92.10 \mathrm{a}$ \\
\hline
\end{tabular}

For each storage factor, means followed by the same letter in the column do not differ statistically by $t$ test at $\mathrm{P}<0.05$.

to dehydration and storage at low temperatures (Bovi \& Cardoso, 1978; Andrade \& Pereira, 1997). The recalcitrant behavior of Euterpe seeds hinders the conservation after physiological maturity, even for a few weeks or months. In order to improve germination and conservation of seeds from palms of the Euterpe genera, fruit depulping is recommended. The fruits of these palms have oleaginous pulps, rich also in sugars, allowing easy development of phytopathogenical microorganisms, which impair the germination process (Bovi et al., 1987). For this reason, E. edulis seed longevity is relatively low, and is recommended immediate sowing it after fruit harvesting and depulping (Bovi et al., 1987). However, operational problems, such as the distance between the harvesting and the sowing areas, the number of harvested fruits, the lack of available labor and difficulties in seed transportation, can delay depulping or sowing. In those cases, the storage of propagules would be necessary, even for a short period, under favorable environmental conditions to the physiological quality maintenance. Several reports indicate that E. edulis seed storage should be accomplished in plastic packing to avoid dehydration and consequent viability loss (Bovi et al., 1987; Nodari et al., 1998). Storage temperatures for this species have been reported to vary from $3-20^{\circ} \mathrm{C}$, depending on the consulted literature (Bovi \& Cardoso, 1978; Bovi et al., 1987; Andrade \& Pereira, 1997; Nodari et al., 1998).

The objectives of the present paper were to determine how long the jussara fruits and seeds can remain stored, waiting for sowing, without seed damage, and to identify appropriate temperature conditions for storage during that period.

\section{MATERIAL AND METHODS}

Mature fruits of jussara were collected manually from 24 palms by the end of March 1998, in the Instituto Agronômico, located in Ubatuba

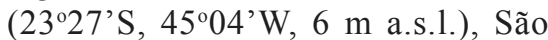
Paulo, Brazil. The fruits were transported in closed plastic bags, under uncontrolled environmental conditions, during approximately 7 hours, to the laboratory of the Universidade Estadual Paulista, in Botucatu, São Paulo State, Brazil, where the assay was conducted.

In the laboratory the fruits were homogenized and cleaned, and inert material, as well as deformed, damaged, or small fruits (below diameter of 10.31 $\mathrm{mm}$, separated by sieve of round hole, size 26/64"') were discarded. Fruits were divided in two lots, and one of them had the seeds depulped through friction against a steel mesh sieve, under running water. Two types of seeds were obtained: with and without pulp. Short-term seed storage of both types (with and without pulp) was accomplished in chambers regulated to temperatures of $5 ; 10 ; 15$ and $20-30^{\circ} \mathrm{C}$. For storage, seeds with and without pulp were packed in well-closed $20 \mu \mathrm{m}$ thick plastic bags (approximately 1200-1400g/bag), with three needle size 12 perforations. Quality evaluation tests were performed using samples of both seed types, stored at four different temperatures for $0 ; 3 ; 6 ; 9$ and 12 days after fruit harvesting. Seeds stored with pulp were shelled, also through friction on sieve, immediately before the establishment of germination tests and seed water content determination.

Seeds water content was evaluated gravimetrically $\left(103 \pm 2^{\circ} \mathrm{C}\right.$ for 17 hours $)$, utilizing three replicates of seven seeds each, following standard procedures (International Seed Testing Association, 1993). Water content was evaluated on the date of fruit harvesting and after the several storage periods. 
Table 2. Interaction effects between pulp and temperature and interaction effects between pulp and time on Euterpe edulis seed germination and vigor. Botucatu, UNESP, 1998.

\begin{tabular}{|c|c|c|c|c|c|c|c|c|}
\hline \multirow{2}{*}{ Treatments } & \multirow{2}{*}{$\begin{array}{l}\text { Seedling dry } \\
\text { weight (mg/ } \\
\text { seedling) }\end{array}$} & \multicolumn{3}{|c|}{ Seedling length $(\mathrm{mm})$} & \multirow{2}{*}{$\begin{array}{c}\text { Rotted } \\
\text { germinative } \\
\text { button }\end{array}$} & \multirow[t]{2}{*}{$\begin{array}{c}\text { Abnormal } \\
\text { seedling }\end{array}$} & \multirow{2}{*}{$\begin{array}{l}\text { Dead seed } \\
\%) \\
\end{array}$} & \multirow[t]{2}{*}{$\begin{array}{c}\text { Final } \\
\text { germination }\end{array}$} \\
\hline & & Plumule & Radicle & Total & & & & \\
\hline \multicolumn{9}{|l|}{ Interaction (PxT) } \\
\hline \multicolumn{9}{|l|}{ With pulp } \\
\hline $5^{\circ} \mathrm{C}$ & $11.31 \mathrm{bc}$ & $9.67 \mathrm{ab}$ & $31.06 a b$ & $40.50 a b$ & $1.80 \mathrm{ab}$ & $1.40 \mathrm{a}$ & $7.20 \mathrm{~b}$ & $89.60 \mathrm{a}$ \\
\hline $10^{\circ} \mathrm{C}$ & $12.32 \mathrm{a}$ & $9.71 \mathrm{ab}$ & $33.14 \mathrm{a}$ & $42.86 \mathrm{a}$ & $1.20 \mathrm{~b}$ & $1.40 \mathrm{a}$ & $6.40 \mathrm{~b}$ & $91.00 \mathrm{a}$ \\
\hline $15^{\circ} \mathrm{C}$ & $12.08 \mathrm{ab}$ & $9.81 \mathrm{a}$ & $32.42 \mathrm{a}$ & $41.68 \mathrm{ab}$ & $1.00 \mathrm{~b}$ & $1.40 \mathrm{a}$ & $6.60 \mathrm{~b}$ & $91.00 \mathrm{a}$ \\
\hline $20-30{ }^{\circ} \mathrm{C}$ & $10.82 \mathrm{c}$ & $9.29 \mathrm{~b}$ & $29.82 \mathrm{~b}$ & $39.11 b$ & $3.00 \mathrm{a}$ & $1.00 \mathrm{a}$ & $11.40 \mathrm{a}$ & $84.60 \mathrm{~b}$ \\
\hline \multicolumn{9}{|l|}{ Without pulp } \\
\hline $5^{\circ} \mathrm{C}$ & $12.97 \mathrm{ab}$ & $10.12 a b$ & $34.25 \mathrm{a}$ & $44.37 \mathrm{a}$ & $1.80 \mathrm{a}$ & $1.40 \mathrm{a}$ & $7.00 \mathrm{a}$ & $89.80 \mathrm{a}$ \\
\hline $10{ }^{\circ} \mathrm{C}$ & $12.98 \mathrm{ab}$ & $10.13 a b$ & $35.26 \mathrm{a}$ & $44.70 \mathrm{a}$ & $1.20 \mathrm{a}$ & $0.40 \mathrm{a}$ & $5.20 \mathrm{a}$ & $93.20 \mathrm{a}$ \\
\hline $15^{\circ} \mathrm{C}$ & 13.49 a & $10.41 a$ & $35.29 \mathrm{a}$ & 45.64 a & $1.00 \mathrm{a}$ & $1.60 \mathrm{a}$ & $5.60 \mathrm{a}$ & $91.80 \mathrm{a}$ \\
\hline $20-30^{\circ} \mathrm{C}$ & $12.45 \mathrm{~b}$ & $9.92 \mathrm{~b}$ & $33.93 \mathrm{a}$ & $43.85 \mathrm{a}$ & $1.40 \mathrm{a}$ & $0.80 \mathrm{a}$ & $4.20 \mathrm{a}$ & $93.60 \mathrm{a}$ \\
\hline \multicolumn{9}{|l|}{ Interaction (PxD) } \\
\hline \multicolumn{9}{|l|}{ With pulp } \\
\hline 0 days & $9.67 \mathrm{~d}$ & $9.33 \mathrm{~b}$ & $29.35 \mathrm{c}$ & $38.67 \mathrm{c}$ & $2.00 a b$ & $1.00 \mathrm{a}$ & $9.00 a b$ & $88.00 \mathrm{~b}$ \\
\hline 3 days & $11.66 \mathrm{bc}$ & $9.47 \mathrm{~b}$ & $32.84 a b$ & $42.31 \mathrm{ab}$ & $1.50 \mathrm{ab}$ & $2.50 \mathrm{a}$ & $8.00 a b$ & $88.00 \mathrm{~b}$ \\
\hline 6 days & $11.16 \mathrm{c}$ & $9.03 b$ & $30.60 \mathrm{bc}$ & $39.18 b c$ & $2.00 a b$ & $1.25 \mathrm{a}$ & $9.50 \mathrm{a}$ & $87.25 b$ \\
\hline 9 days & $13.04 \mathrm{a}$ & $10.12 \mathrm{a}$ & $33.90 \mathrm{a}$ & $43.78 \mathrm{a}$ & $3.00 \mathrm{a}$ & $1.00 \mathrm{a}$ & $7.75 a b$ & $88.25 b$ \\
\hline 12 days & $12.64 \mathrm{ab}$ & $10.15 a$ & $31.38 a b c$ & $41.25 \mathrm{abc}$ & $0.25 \mathrm{~b}$ & $0.75 a$ & $5.25 b$ & $93.75 \mathrm{a}$ \\
\hline \multicolumn{9}{|l|}{ Without pulp } \\
\hline 0 days & $9.67 \mathrm{c}$ & $9.33 c$ & $29.35 \mathrm{c}$ & $38.67 \mathrm{c}$ & $2.00 a b$ & $1.00 \mathrm{a}$ & $9.00 \mathrm{a}$ & $88.00 \mathrm{~b}$ \\
\hline 3 days & $11.91 b$ & $9.61 \mathrm{bc}$ & $34.05 \mathrm{~b}$ & $43.66 \mathrm{~b}$ & $2.25 \mathrm{a}$ & $1.25 \mathrm{a}$ & $5.00 \mathrm{ab}$ & $91.50 a b$ \\
\hline 6 days & $12.59 \mathrm{~b}$ & $9.94 \mathrm{~b}$ & $34.19 \mathrm{~b}$ & $43.92 \mathrm{~b}$ & $1.00 \mathrm{ab}$ & $1.50 \mathrm{a}$ & $3.75 \mathrm{~b}$ & $93.75 \mathrm{a}$ \\
\hline 9 days & $15.19 \mathrm{a}$ & $10.85 a$ & $38.16 \mathrm{a}$ & $49.02 \mathrm{a}$ & $1.50 a b$ & $1.00 \mathrm{a}$ & $5.25 a b$ & $92.25 a b$ \\
\hline 12 days & $15.51 \mathrm{a}$ & $10.99 \mathrm{a}$ & $37.66 \mathrm{a}$ & $47.92 \mathrm{a}$ & $0.00 \mathrm{~b}$ & $0.50 \mathrm{a}$ & $4.50 \mathrm{~b}$ & $95.00 \mathrm{a}$ \\
\hline
\end{tabular}

For each storage factor, means followed by the same letter in the column do not differ statistically by $\mathrm{t}$ test at $\mathrm{P}<0.05$.

The germination tests were performed on four replications of 25 seeds per treatment, under alternate temperature $\left(20-30^{\circ} \mathrm{C}\right)$ and light $(78$ $\left.\mu \mathrm{mol} \mathrm{s}{ }^{-1} \mathrm{~m}^{-2} / 8 \mathrm{~h}\right)$, on sterilized $\left(120^{\circ} \mathrm{C} /\right.$ $12 \mathrm{~h}$ ) and humidified vermiculite, inside plastic boxes. The germination tests ended 34 days after sowing. The percentages of normal and abnormal seedlings, as well as dead seeds, were calculated. Rotted germinative buttons (emitted but rotted before plumule differentiation) were also counted and evaluated.

Plumule and radicle lengths $(\mathrm{mm})$ were measured at the end of germination tests. The population of normal seedlings was considered, for the calculation of replication means. Seedling dry matter was also determined at the end of the germination test. Normal seedlings were carefully detached from seeds by torsion, dried at $80^{\circ} \mathrm{C} / 24$ hours and weighted after cooled in desiccator for 15 minutes.

The experimental design was a completely randomized factorial arrangement of $5 \times 4 \times 2$ (storage days $\mathrm{x}$ temperatures $\mathrm{x}$ pulp), with four replications per treatment. Variance analysis was applied to data, and means comparisons were performed by $t$ test $(5 \%)$. Germination and seedling dry matter (the best indicative of seed vigor) responses were modeled by polynomial function, with linear, quadratic and cubic effects, using stepwise regression and maximum determination coefficient statement (Steel \& Torrie, 1980). This procedure allowed the estimative of variables not tested, but within the studied range, as for example, seed germination and vigor responses for the $20^{\circ} \mathrm{C}$ storage temperature.

\section{RESULTS AND DISCUSSION}

The coefficient of variation of the experiment was low for normal distributed variables, as germination and seedling weight and length (ranging from 5.57 to $9.26 \%$ ), and high (61.90 to $177.84 \%$ ), as expected, for rotted, dead and abnormal seeds and seedlings.

Significant differences were detected, between times, temperatures and pulp (presence or absence), during seed short-time storage, for almost all studied traits, except abnormal seedling percentage. There were significant simple (two factors) interactions between almost all the studied factors, showing that shelled and unshelled fruits have different behavior as a function of temperature and days of storage. The highly significant interaction between temperature and pulp 


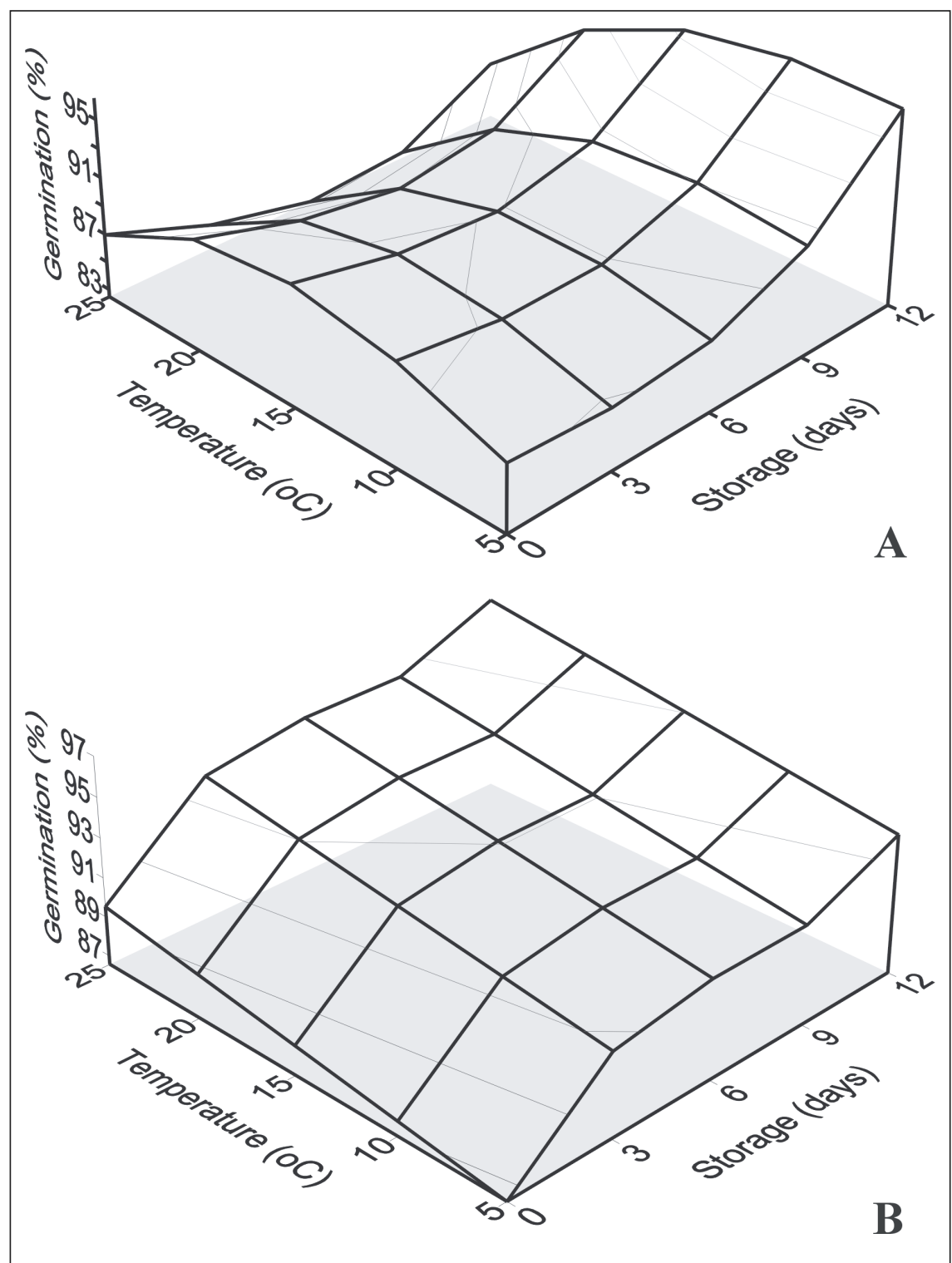

Figure 1. Germination percentage of fruits (a) and seeds (b) of Euterpe edulis as a function of days and temperatures of storage. Botucatu, UNESP, 1998.

for dead seeds and final germination percentage $(\mathrm{F}=104 ; 27 * *$ and $164 ; 37 * *$, both significant at 0.01 probability level, respectively) highlights the importance of the presence or absence of pulp in the short-time storage of Euterpe edulis seeds.

The seed water content (Table 1) presented low variation, ranging from 49.4 to $50.1 \%$, and was not affected by any of the treatments imposed on jussara seeds (time, temperature and pulp). Therefore, the germinative seed performance, in response to the applied treatments, was considered exempt from the possible effects that the differences in seed water content could provoke.
The means for the storage time, as isolated factor (Table 1), indicated that seed germination and vigor (this last one assessed by seedling dry matter and length) were progressively increased with storage time, although, by the statistical test applied, they have overcome significantly the control only after 12 days of storage, for germination, and after 9 days for vigor. When regression analysis and surface response methods were applied to the data, a positive effect of time and temperature of storage over germination and vigor could be visualized (Figures 1 and 2). Seeds stored without pulp had higher germination and vigor, when compared to whole fruits (Table 2), in all temperatures and times tested. They showed also slightly different responses to storage temperatures. Whereas maximum germinative response $(96 ; 43 \%)$ was found between 15 and $20^{\circ} \mathrm{C}$ for seeds stored with pulp, a positive linear temperature response (varying from $86 ; 55 \%$ at $5^{\circ} \mathrm{C}$ to $96 ; 52 \%$ at $20-30^{\circ} \mathrm{C}$ ) was found for shelled seeds (Figures $1 \mathrm{a}$ and $1 \mathrm{~b}$ ).

Seeds stored with pulp, under temperature of $20-30^{\circ} \mathrm{C}$, presented microorganisms on their surface, specially after the $6^{\text {th }}$ day of storage, and a more intense fermentation process than other treatments. That could explain the increase of rotted and dead seeds and the decrease in the germination percentage of whole fruits stored at higher temperature, when compared to seeds without pulp (Table $2)$. When the factor pulp was analyzed isolated (Tables 1 and 2), the seed storage without pulp favors the germinative performance of jussara seeds and seedlings. The storage of the seed with pulp (whole fruit), which is oleaginous and rich in sugars, allows microorganisms development and seed coat fermentation, causing embryo damage and, consequently, viability loss and germination rate reduction, corroborating earlier results obtained by Bovi et al. (1987), Lin (1986) and also, more recently, by Nodari et al. (1998).

Additionally, it seems that seeds stored with pulp were less favored by the time of storage (after-ripening process) than the seeds without pulp, specially when stored at high temperatures, as can be observed in Figures $1 \mathrm{a}$ and $1 \mathrm{~b}$, for the germination percentage, and in Figures $2 a$ and $2 b$, for the seedling dry weight.

Taking the storage temperature as an isolated factor (Table 1), temperatures of $5 ; 10$ and $15^{\circ} \mathrm{C}$ allowed the maintenance of the physiological quality of the seeds, although a superiority tendency has been observed, in absolute values, for the temperatures of 10 and $15^{\circ} \mathrm{C}$, specially for the unshelled seeds. This is expected, as Euterpe palms are species from tropical and sub-tropical habitats (Orlande et al., 1996; Matos \& Watkinson, 1998) and the range of 
favorable storage temperature found in the present assay, comprises, partially, those indicated by Andrade \& Pereira (1997) (5 and $\left.20^{\circ} \mathrm{C}\right)$, Bovi \& Cardoso (1978) $\left(5\right.$ to $\left.10^{\circ} \mathrm{C}\right)$ and also by Bovi et al. (1987) $\left(5\right.$ to $\left.10^{\circ} \mathrm{C}\right)$.

For the storage of seeds with pulp (whole fruit), the temperatures of 5; 10 or $15^{\circ} \mathrm{C}$ were equally efficient for seed physiological quality maintenance, observed through the percentage of germination. Although less intense, this effect was also verified through seedling dry matter and length (Table 2). For seeds without pulp, the tested temperatures did not influence most of the appraised characteristics significantly, although the seedling dry matter and plumule length have indicated a tendency of better response in storage temperatures of 10 and $15^{\circ} \mathrm{C}$ (Table 2). Nonetheless, low temperature $\left(5^{\circ} \mathrm{C}\right)$ for a short-time period (0 to 12 days) did not affect negatively the germination and vigor of Euterpe edulis seeds. Neither higher temperature (estimated $20^{\circ} \mathrm{C}$ and tested $20-30^{\circ} \mathrm{C}$ ) affected the germinative performance of shelled seeds (Figures $1 \mathrm{~b}$ and $2 \mathrm{~b}$ ).

Taking into consideration the seed response to the applied treatments, the climatical conditions of this species in its natural habitat, where day-night temperatures ranged from 30 to $20^{\circ} \mathrm{C}$ (Orlande et al., 1996; Matos \& Watkinson, 1998), and earlier seed research results (Bovi et al., 1987), it is suggested that, in those regions of natural species occurrence, jussara seed storage is possible only if already depulped and conditioned in plastic bags. In cases where there are no conditions of an immediate fruit depulping, they can be stored in temperatures between 5 and $15^{\circ} \mathrm{C}$. This temperature range can be easily obtained in domestic refrigerators, and is technical feasible to be applied by producers or research stations in the seed collecting areas.

The results reported in the present research indicate that the seeds of $E$. edulis need a period of storage before sowing, in order to complete embryo maturation. The after-ripening process of fruits and seeds was reported in the literature for other species, especially

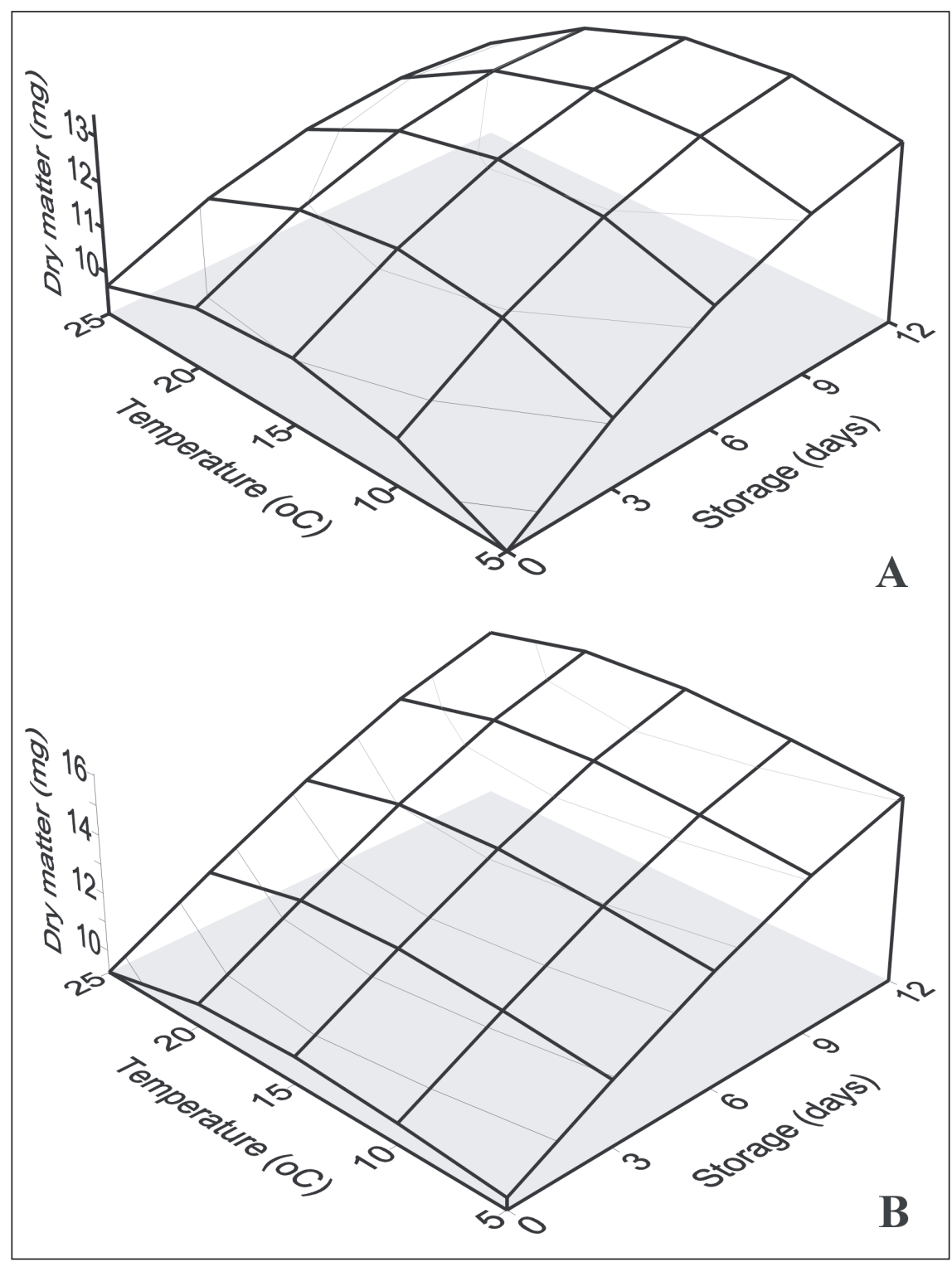

Figure 2. Seedling dry matter (mg) of fruits (a) and seeds (b) of Euterpe edulis as a function of days and temperatures of storage. Botucatu, UNESP, 1998.

fruit crops, as mentioned by Nikolaeva (1977). This author pointed out that immature embryos, recognized as one of the causes of slow germination in palms, has an important ecological meaning since, by delaying the germination process, it contributes to a better seedling emergence distribution in the long run.

As significant response to storagetime was found for germination and vigor until 12 days, as clearly observed in figures 1 and 2, it is suggested that periods greater than that should be tested, especially for unshelled jussara seeds, using temperatures ranging from 5 to $20-30^{\circ} \mathrm{C}$, or even for whole fruits stored at low temperatures $\left(5\right.$ to $15^{\circ} \mathrm{C}$, for example).

\section{ACKNOWLEDGEMENTS}

This research was made possible through support of the FAPESP, São Paulo State, Brazil.

\section{LITERATURE CITED}

ANDRADE, A.C.S.; PEREIRA, T.S. Comportamento de armazenamento de sementes de palmiteiro (Euterpe edulis Mart.). Pesquisa Agropecuária Brasileira, Brasília, v.32, n.10, p.987-991, 1997.

BOVI, M.L.A.; CARDOSO, M. Conservação de sementes de palmiteiro (Euterpe edulis Mart.). Bragantia, Campinas, v.37, n.1, p.65-71, 1978. 
BOVI, M.L.A.; GODOY-JUNIOR, G.; SAES, L.A. Pesquisas com os gêneros Euterpe e Bactris no Instituto Agronômico de Campinas. Agronômico, v.39, n.2, p.129-174, 1987.

GALETTI, M.; FERNANDEZ, J.C. Palm heart harvesting in the Brazilian Atlantic forest: changes in industry structure and the illegal trade. Journal of Applied Ecology, v.35, n.2, p.294-301, 1998.

INTERNATIONAL SEED TESTING ASSOCIATION. International rules for seed testing. Rules 1993. Seed Science and Technology, v.21, n.1, p.1-75, 1993.

LIN, S.S. Efeito do tamanho e maturidade sobre a viabilidade, germinação e vigor do fruto de palmiteiro. Revista Brasileira de Sementes, v.8, n.1, p.57-66, 1986.
MATOS, D.M.S.; BOVI, M.L.A. Understanding the threats to biological diversity in southeastern Brazil. Biodiversity and Conservation, v.11, n.4, p.1747-1758, 2002.

MATOS, D.M.S.; WATKINSON, A.R. The fecundity, seed, and seedling ecology of the edible palm Euterpe edulis in Southeastern Brazil. Biotropica, v.30, n.4, p.595-603, 1998.

NIKOLAEVA, M.G. Factors controlling the dormancy pattern. In: KHAN, A.A. (ed.) The physiology and biochemistry of seed dormancy and germination. Amsterdam: North-Holland Publishing Company, 1977, p.51-71.
NODARI, R.O.; FANTINI, A.C.; GUERRA, M.P.; REIS, M.S.; SCHUCH, O. Conservação de frutos e sementes de palmiteiro (Euterpe edulis Mart.) sob diferentes condições de armazenamento. Revista árvore, v.22, n.1, p.1-10, 1998.

ORLANDE, T.; LAARMAN, J.; MORTIMER, J. Palmito sustainability and economics in Brazil's Atlantic coastal forest. Forest Ecology and Management, v.80, n.3, p.257-265, 1996.

STEEL, R.G.; TORRIE, J.H. Principles and procedures of statistics. New York: MacGraw-Hill, 1980. $632 \mathrm{p}$. 